Ethiopian Journal of Environmental Studies \& Management 7(2): 160 - 170, 2014.

ISSN:1998-0507

doi: http://dx.doi.org/10.4314/ejesm.v7i2.7

Submitted: November 22, 2013

Accepted: March 4, 2014

\title{
URBAN INFRASTRUCTURE CONDITION AND NEIGHBOURHOOD SUSTAINABILITY: A CONTINGENT VALUATION APPROACH
}

\author{
OTEGBULU, A.C. \\ Department of Estate Management, University of Lagos \\ Email: austinotegbulu@yahoo.com
}

\begin{abstract}
The aim of this paper is to demonstrate the implication of infrastructure condition to urban neighbourhood sustainability and how a demand driven approach can enhance willingness to pay for service improvement. The study is a survey research carried out through the distribution of structured questionnaires to 1040 households in 8 metropolitan local government areas namely; Alimosho, Apapa, Eti-osa, Ikeja, Shomolu, Mushin, Kosofe and Surulere. The questionnaire was designed to elicit information on households' preferences and demand for urban infrastructure including willingness to pay and averting expenditure. Findings from the study indicated that different areas of the city have preferences for different infrastructure both in specific types and service option, and that demand driven provision will enhance WTP and has implication to neighbourhood sustainability. It will also encourage cost recovery and public sector participation in infrastructure provision.
\end{abstract}

Key words: Demand side management, infrastructure, sustainability, urban neighbourhood, willingness to pay.

\section{Introduction}

The World Bank in a review of its lending in the infrastructure sector called for a new focus on the flow of services, as well as on demand of preferences of users and their willingness to pay for services provided. The report calls for greater use of the private sector and encourages community participation in project design. It also noted that many infrastructure services do not have good sustainability over the long term. There is need to focus more on end user preferences and to give attention to the quality of services being delivered. Stressing the need to respond to customers implies an enormous psychological shift in the command approach manner infrastructure is delivered in the past (World bank 2006; Andres et al., 2008; Mobogunje, 1993).

Infrastructure acts as the spinal cord that links people, social institutions, socioeconomic activities, and natural environment into a coherent urban relationship. It is the key component for providing an enabling environment for sustainable growth. It is equally essential for safeguarding health, protecting the environment, and promoting the efficient operation of human settlements (Andreas et al., 2008, Goodman and Hastak, 2006; Arrosi, 1996). Providers of public infrastructure must consider user need and preferences in their policy and decisionmaking. Deciding on the infrastructure budget actually involves choosing a set of individual projects from the range of options that cover all infrastructure types. These multi-sectoral decisions are complex both because of information requirement and because responsibility may be spread across several ministries and several levels of government. Infrastructure provision could be viewed from both the supply (top bottom) and demand side (bottom - top) or a combination of both. From the supply side, the focus is on how infrastructure influences the economy. Better water, sewer, roads, and other services are expected to expand overall economic potential by allowing firms to be more productive. On the other hand, infrastructure provision may be prompted to meet demand for services.

Willingness to pay (WTP) for services will be much greater and resources will then be used in ways that lead to increased satisfaction if infrastructure is built where there is sufficient demand for the services (subject to affordability). Demand must be measured so that sufficient capacity is installed to allow for future expansion arising from reasonable growth in demand. It is also influenced by household's income, the price of the service provided, number of service hours among 
others. (Mycoo, 2005; Choynowski, 2002; Otegbulu, 2011; Fox, 1995; Kessides, 2001).

Public preferences for these services must be reflected either through communal organizations, such as neighbourhood associations, or through a formal governance process such as elective representation or survey using questionnaire carried out in a democratic manner.

Infrastructure provision has remained a major problem in developing countries like Nigeria due to poor financing by government and inadequate incentive to attract private participation. Housing and infrastructure provision are costly and the inability of government to satisfy the demand of citizens has led to the proliferation of slums and informal squatter settlements. The physical characteristics of these settlements bear testament to the lack of physical infrastructure: water logged muddy ground due to poor drainage, ill-defined access way and unpaved roads and long queues to obtain water from single public tap or expensive water vendors. The poor conditions of infrastructure have obvious implications for the health and economic condition of urban residents. This could result in less money for food and consequently lower nutritional status, which itself increases vulnerability to disease. It is interesting to observe that the inhabitants of improved informal settlements have demonstrated the ability to improve their environment through ingenuity and improvisation in situations where government has been unable to provide infrastructure (UN-HABITAT 2008). This situation has obvious implication to environmental, social and economic sustainability.

There is always a link between demand/supply, WTP and sustainability as households/users are the major clients for infrastructure and its provision must be in response to households' effective demand. The implication of this is that demand preferences coupled with averting expenditure and WTP will help in the planning of sustained infrastructure provision and tariff regime. According to Gunatilake 2006, basic economic principle suggests that monthly charges should be equal to or less than WTP. This is based on the argument that tarrif charges above WTP will lead to welfare losses and may discourage households from connecting to services. However, Otegbulu (2011) opined that tariff should be adopted between averting cost and WTP taking into consideration market size, capital and recurrent costs and level of demand. He further suggests that the averting cost could be an indication of the maximum cost that could be allowed by the budget and income of the consumer.

Infrastructure provision in Nigeria and other third world countries are characterized by command or top-bottom approach. The need to place users/stakeholders at the Centre of decision making will lead to the provision of services that are in tandem with people's demand. This will enhance their willingness to pay for the services provided and provide a good incentive for cost recovery, and service/neighbourhood sustainability.

Urban households rely heavily on urban infrastructure. Infrastructure services such as clean water, transport, and communications are important consumption benefits, and their availability is a measure of basic welfare of the population, as they have direct impact on their life style. Besides their direct value as an item in the "consumption basket "of households, infrastructure services are a means to acquiring other goods and services. The direct and indirect consumption benefits from electric power, for example, includes the extra hours of study time due to electric lighting, the availability of new forms of entertainment (e.g. cinema, television) and access to labour saving appliances. In addition, the price of infrastructure services relative to other items affect the level of overall consumption which households can achieve within a given budget constraint . (Kessides, 1995; Samulson and Nordhaus, 2005; Calderon and Server, 2008). The constraints referred to are cash income and time. (Kessides, 1995 and 2004)

The value to any household of any infrastructure can be inferred quantitatively, at least in part, from the analysis of three types of behaviours: willingness to pay, allocation of expenditure and allocation of time.

As an example of the first, a study of the informal sector water vending in Onitsha, Nigeria reveals that the vast majority of households were not serviced by the municipal public water distribution system, and instead were purchasing water from private vendors at price that were 20 times higher than those of the public utility (Kessides, 1995 and 2004).

According to Montes De Oca and Bateman (2006) many urban areas in 
developing countries face severe and long time challenges regarding the sustainability of their water supplies and other infrastructure.

The new focus on "customers" shows that agencies are realizing that user preferences and satisfaction of those who receive the services are more reliable indicators of project longterm success than supply side, top-down indicators. Do the people served need or want the services enough to pay for them and to be involved in their upkeep? Is it the kind of service they need, and at the price they can afford? By responding to "effective demand," which has its roots in community participatory style of planning, infrastructure projects can avoid the pit-fall of being constructed without input from users who will be responsible for its upkeep and maintenance. With public finance stretching to the limit in many countries and states, users' willingness to pay for on -going services has become a crucial ingredient in project design.

The World Bank now insists on cost recovery in place of subsidy. Infrastructure is more likely to be economically efficient, and to have favourable impacts on the environment, when subjected to user charges. User charges are necessary to elicit effective demand and discourage wasteful consumption. The absence of user charges has usually not promoted access to services by the poor, but rather reduced availability and worsened inequalities (Kessides, 1993). According to the World Bank (2006), a key lesson learned from this experience is the importance of paying close attention to the micro-level institutional and operational arrangement for demand-driven and, sustainable infrastructure project at the local level.

Sustainability issues are relevant at all levels from the individual to the organizations (of a business or other nature) to municipalities, cities and regions. Small changes in the direction of more sustainable society could be part of radical transformation processes (Soderbaum, 2008).

Inadequate financial rate of return, however, undermines the sustainability of infrastructure projects, and in extreme cases can produce "white elephants". Reliable financial projections at the project approval stage are essential to avoid this. The development of more sustainable cities critically depends on the style of urban infrastructure provision that encourages more efficient patterns of resource consumption.
Conventional practices of network management-facilitating infrastructure supply, (FIS) has a powerful tendency to predict and provide service options with forecasts of increasing demand met in advance through supply-oriented options. In contrast, Demand Side Management (DSM) approaches attempt to avoid environmentally and economically expensive investment by managing both the level and timing of demand on Networks. Sustainability in infrastructure provision may not be possible without the prospect of cost recovery to be properly established. The sustainability of urban neighbourhood is directly linked to the sustainability of infrastructure services in terms of economic, growth, ecological balance and social progress. If provision of urban services is to be substantial and sustainable, it must be profitable to its providers and affordable to its users. This is the only way infrastructural conditions in our cities can be improved sustainably.

\section{Methodology}

The paper aims at showing how user demand preferences will enhance WTP with consideration to its sustainability implication. The study will also determine the various service and specific options for infrastructure and factors affecting infrastructure demand in the study area.

The study is a survey research based on the distribution of structured questionnaires to 1040 households in the study area comprising 8 metropolitan local government areas of Lagos, Nigeria (using stratified and systematic random sampling techniques) out of which 774 (77.4\%) responded. The areas include; Kosofe, Eti-osa, Alimosho, Ikeja, Mushin, Surulere, Apapa and Somolu local government areas.

Questions were asked to elicit information on averting behaviour of households to determine the cost of alternative source of infrastructure and expenses incurred due to poor state of infrastructure. Information was also obtained on preferences for both specific infrastructure and technical options (the manner households prefer the infrastructure provided) and households' willingness to pay for them. Finally data was obtained on factors influencing infrastructure demand and willingness to pay. Four types of infrastructure are subject of this study namely; electricity, water, road and drainage. Drainage was not considered for service options as it was treated as part of road in that context. 
Analysis was carried out with the use of both descriptive and inferential statistics. Relative impact index is used to analyze households' preference ranking.

\section{Results}

\section{Respondents' Characteristics}

All the respondents are residents of Alimosho, Apapa, Eti- Osa, Ikeja, Shomolu, Mushin, Kosofe and Surulere Local Government Area. Result from data obtained shows that about 95\%ofthe respondents are above twenty (20) years of age, which shows that majority of the respondents are adults. The essence of securing information on the respondents' qualifications was to be sure that they relatively understood what the survey was about and to some extent, be able to contribute to better infrastructure planning in their locality. The survey result data also shows that at least, $84.7 \%$ of the respondents had higher education (from Ordinary/National Diploma and above).

The questionnaire was targeted at heads or spouses of households. Their mean income is between $\$ 1,200,853$ - 333 , 833 per annum, while household size is mainly between 1 and 10. About $20 \%$ are above 10 in size. Findings from the study shows that most of the households have average education, while majority have lived their respective lives in their respective neighbourhood for more than 7 years. This implies that they have good knowledge of the area which gives more credibility to their response.

Figure 1 shows that most households rely on wells water for domestic use Alimosho (52.6\%), Apapa (57\%), Kosofe (50\%) and Shomolu (66.7\%). Most households use boreholes; in Ikeja local government (54\%). This situation exposes most households to water borne diseases with high cost implication arising from loss of man-hours, and cost of treatment. The situation has sustainability implications.

Figure 2 shows that majority of households in the study area have electricity power supply for between 1-5 hours a day; Kosofe (62.8\%), Shomolu (60\%), Apapa (50\%), Alimosho $(40 \%)$, Mushin $(34 \%)$ and Surulere $(32.3 \%)$. Some do not even have power supply for some days. In the absence of reliable electricity supply resort will be made to improvised electricity sources like generators, candles, lanterns etc. some of the improvised sources are not environmentally friendly and constitutes a threat to environmental sustainability.

Figure 3 below shows that more than $60 \%$ of households in the study area use generators on a daily basis. Apapa and Alimosho have the highest percentage of $83.3 \%$ and $73.1 \%$ respectively. The implication of this is the increase in informal source of energy which is inferior and more expensive. In addition, it produces air and noise pollution, and increases global warming. This has obvious implication to environmental sustainability.

From figure 4, a lot of problems emanate from poor road conditions. The nature of road problems varies from local government to local government. In Apapa and Ikeja local government, the greatest problem is narrow roads. In Alimosho and Shomolu, the major problem is potholes. In Eti-osa, Kosofe and Mushin lack of street light in the study area creates insecurity at night. Potholes had been causing accidents and damages to cars, delay in traffic movement and robbery at hold-ups.

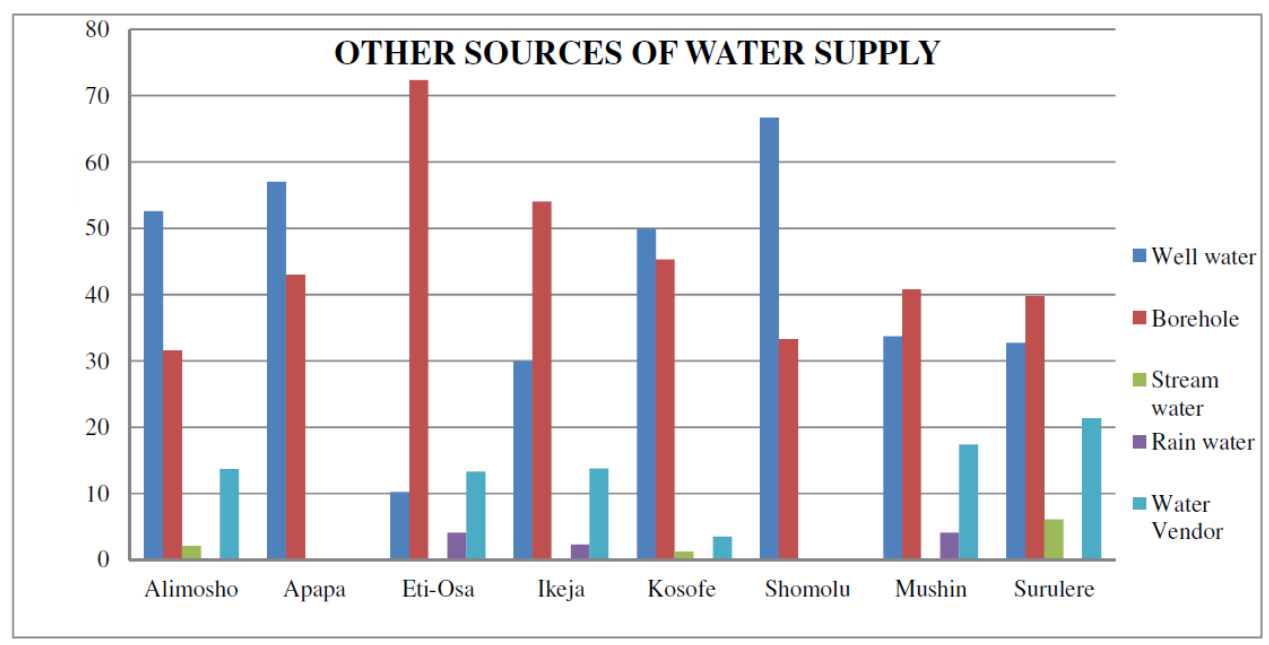

Figure 1: Other Sources of Water Supply 


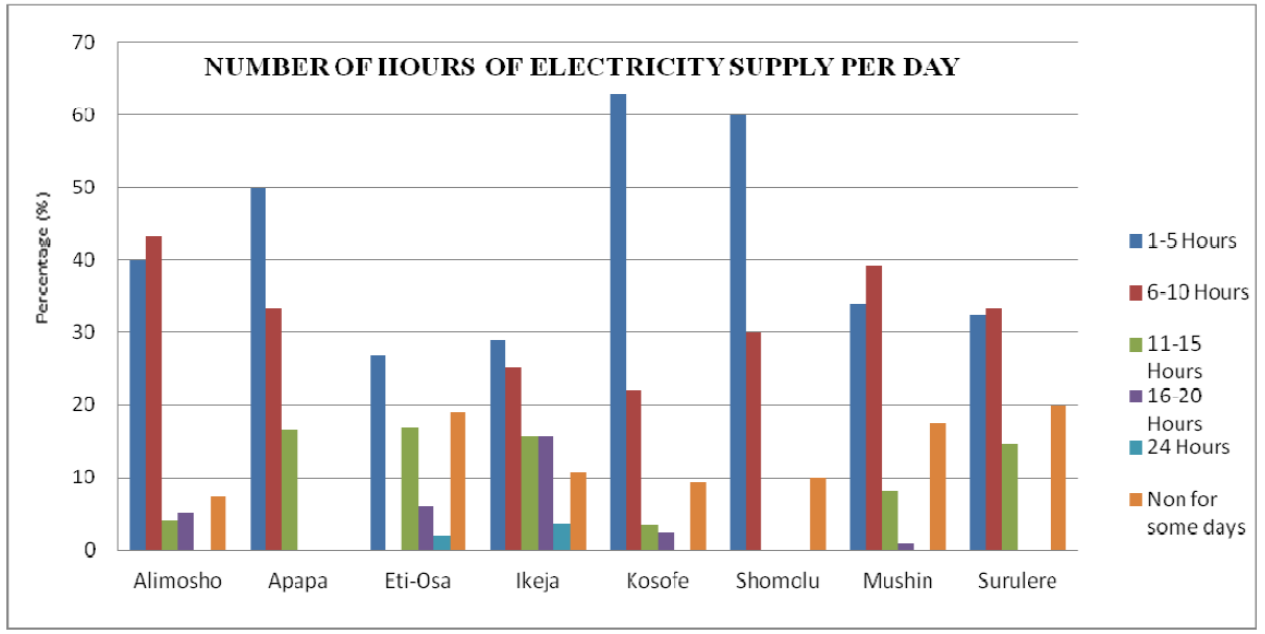

Figure 2: Number of Hours of Electricity Supply per Day

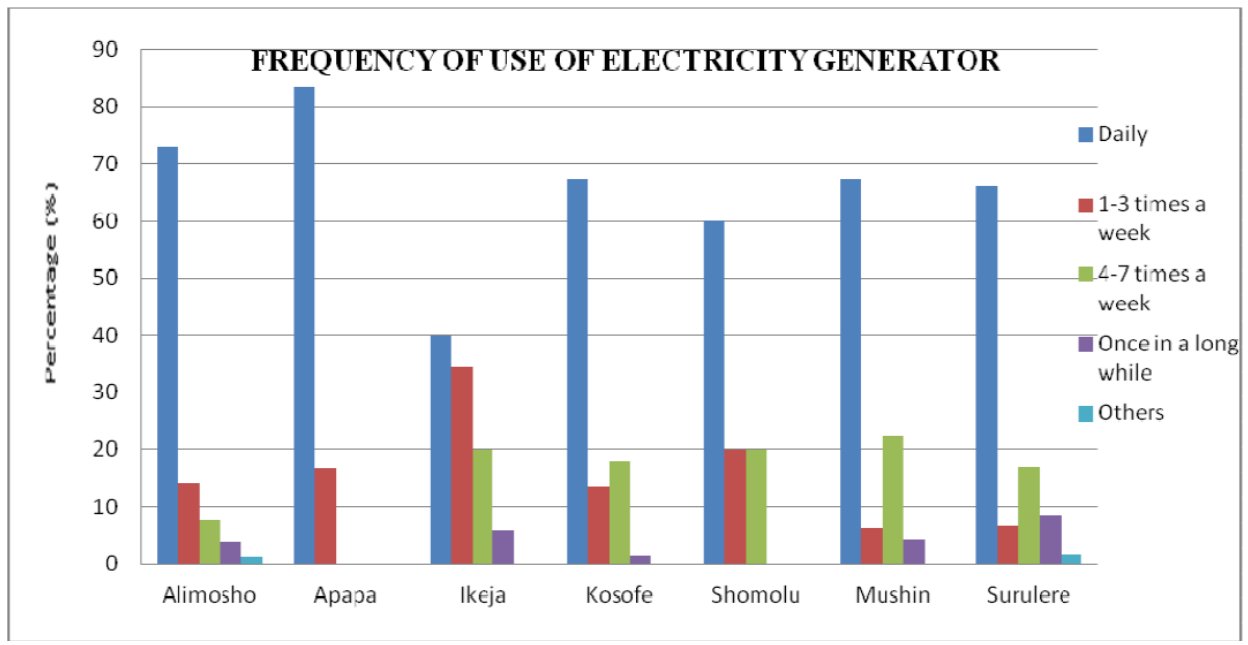

Figure 3: Frequency of Use of Electricity Generator

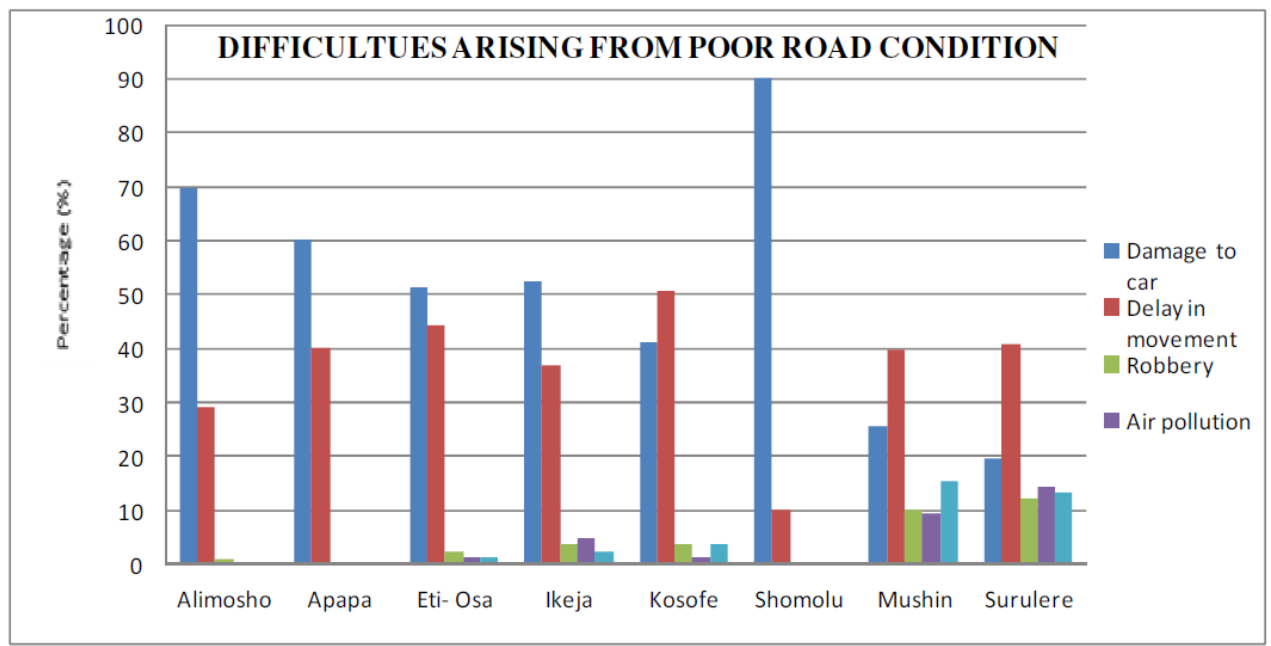

Figure 4: Difficulties Arising From Poor Road Condition

Based on the result from figure 5 below, it takes between $1-6$ hours for flood to clear in most parts of the study area. The results shows that; Ikeja (66.7\%), Surulere (52\%), Mushin (50.6\%), Kosofe (48.4\%), Eti - Osa (37.5\%), Alimosho (36\%) and Apapa (33\%). The implication of this is that, most of those affected cannot move out from their homes until the flood clears up reasonably, it will lead to loss of man hours. The situation impacts on both economic and environmental sustainability of the study area. According to Ogu (2000), the sustainability of urban neighbourhood is directly linked to the sustainability of urban infrastructure services in 
terms of economic growth, ecological balance and social progress.

Data from figure 6 shows that most households in the study area have open drainage, and drainage filled with sludge. For example in Alimosho local government they have; open drainage $(41.7 \%)$, Apapa $(28.6 \%)$, Eti - Osa
(34.8\%), Shomolu (70\%), Mushin (26.8\%) and Surulere $(38.1 \%)$. The consequence of poor drainage system is flooding and filthy environment. The problem of flooding associated with this situation affects both environmental and economic sustainability as reported in Ogu (2000).

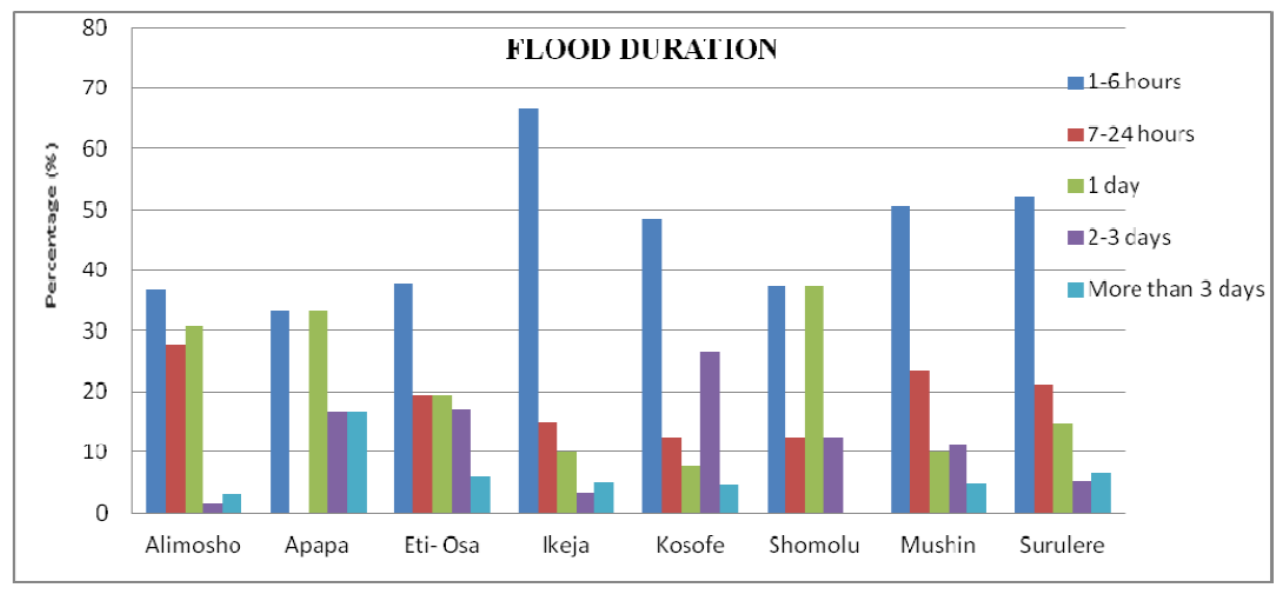

Figure 5: Flood Duration

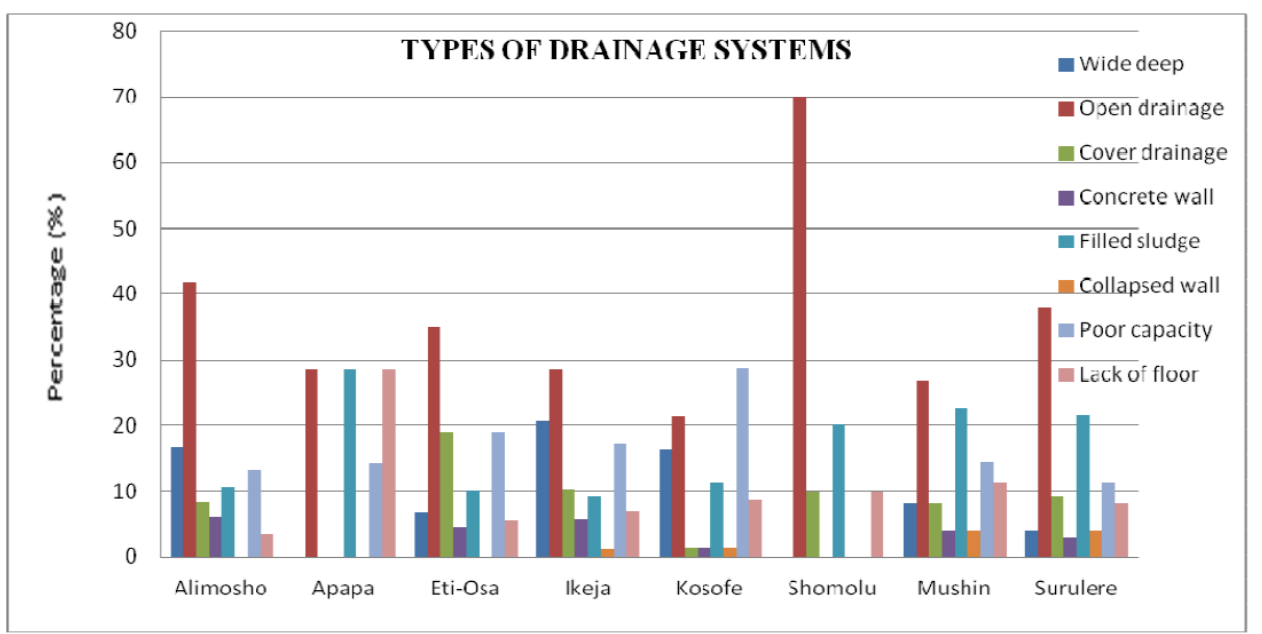

Figure 6: Types of Drainage Systems

Table 1: Preferred Infrastructure in Different Local Government Areas

\begin{tabular}{|c|c|c|c|c|c|c|c|c|c|c|c|c|c|c|c|c|}
\hline \multicolumn{17}{|c|}{ Choice of infrastructure } \\
\hline & \multicolumn{2}{|c|}{ Alimosho } & \multicolumn{2}{|c|}{ Apa } & \multicolumn{2}{|c|}{ Eti-Osa } & \multirow{2}{*}{$\frac{\text { Ikeja }}{\text { RII }}$} & \multicolumn{2}{|c|}{ Kosofe } & \multicolumn{2}{|c|}{ Shomolu } & \multicolumn{2}{|c|}{ Mushin } & \multicolumn{2}{|c|}{ Surulere } & \multirow[b]{2}{*}{$\mathrm{k}$} \\
\hline & $\begin{array}{c}\text { RII } \\
\mathrm{k}\end{array}$ & $\begin{array}{l}\mathrm{R} \\
\mathrm{k}\end{array}$ & RII & $\begin{array}{l}\mathrm{R} \\
\mathrm{k}\end{array}$ & RII & $\begin{array}{l}\mathrm{R} \\
\mathrm{k}\end{array}$ & & $\begin{array}{l}\mathrm{R} \\
\mathrm{k}\end{array}$ & RII & $\begin{array}{l}\mathrm{R} \\
\mathrm{k}\end{array}$ & RII & $\begin{array}{l}\mathrm{R} \\
\mathrm{k}\end{array}$ & RII & $\begin{array}{l}\mathrm{R} \\
\mathrm{k}\end{array}$ & RII & \\
\hline Electricity & 0.94 & 1 & 0.9 & 2 & 0.87 & 1 & 0.96 & 1 & 0.94 & 1 & 0.93 & 1 & 0.93 & 1 & 0.97 & 1 \\
\hline Water & 0.85 & 2 & 0.93 & 1 & 0.77 & 2 & 0.78 & 2 & 0.82 & 2 & 0.68 & 2 & 0.71 & 2 & 0.73 & 2 \\
\hline Road & 0.64 & 3 & 0.5 & 3 & 0.67 & 3 & 0.60 & 3 & 0.56 & 3 & 0.54 & 3 & 0.55 & 3 & 0.58 & 3 \\
\hline Drainage & 0.54 & 4 & 0.5 & 4 & 0.48 & 4 & 0.40 & 4 & 0.38 & 4 & 0.36 & 4 & 0.47 & 4 & 0.44 & 4 \\
\hline
\end{tabular}

Data from table 1 shows that different local government areas have different preferences with respect to infrastructure needs. For example, electricity ranked first in all the local government areas except Apapa where it ranked second and water ranked first. This shows that electricity is a major problem in the study area and needs drastic attention. The findings confirm the need to elicit household's needs and preferences in Infrastructure provision and planning. This confirms the view expressed by (Fox 1995, Otegbulu 2010, Andres et al., 2008), that providing preferred infrastructure will enhance willingness to pay. 
Table 2 shows the type of water connection respondents want in the neighborhood. Water directly connected to the apartment was ranked first; Common standing tap in the compound was ranked second while Fetching from public/street standing taps was ranked third. Also, on method of billing, the respondents preferences are as follows; for electricity prepaid method of billing ranked first while Meter Reading Method ranked second in Alimosho, Apapa, Eti-Osa, Ikeja, Kosofe, Shomolu, Mushin and Surulere Local Government Areas.

Table 2: Service Options

\begin{tabular}{|c|c|c|c|c|c|c|c|c|c|c|c|c|c|c|c|c|}
\hline W ATER & \multicolumn{2}{|c|}{ ALIMOSHO } & \multicolumn{2}{|c|}{ APAPA } & \multicolumn{2}{|c|}{ ETI-OSA } & \multicolumn{2}{|c|}{ IKE,JA } & \multicolumn{2}{|c|}{ KETU } & \multicolumn{2}{|c|}{ SHOMOLU } & \multirow{2}{*}{\multicolumn{2}{|c|}{$\begin{array}{l}\text { MUSHIN } \\
\text { Rk RII }\end{array}$}} & \multicolumn{2}{|c|}{ SURULERE } \\
\hline & Rk & RII & Rk & RII & Rk & RII & Rk & RII & & RII & Rk & RII & & & Rk & RII \\
\hline $\begin{array}{l}\text { Water directly } \\
\text { connected to } \\
\text { apartment }\end{array}$ & 1 & .94 & 1 & .94 & 1 & .92 & 1 & .92 & 1 & .88 & 1 & .88 & 1 & .86 & 1 & .88 \\
\hline $\begin{array}{l}\text { Common standing } \\
\text { tap in the } \\
\text { compound }\end{array}$ & 2 & .81 & 2 & 81 & 2 & .68 & 2 & .70 & 2 & .70 & 2 & .70 & 2 & .70 & 2 & .58 \\
\hline Fetching from & 3 & .59 & 3 & .59 & 3 & .46 & 3 & .58 & 3 & .56 & 3 & .56 & 3 & 46 & 3 & .54 \\
\hline & ALI & OSHO & $\mathbf{A P A}$ & & ETI & OSA & IKE & & $\mathrm{KE}^{\prime}$ & & SHC & MOLU & MUS & SHIN & SUR & LERE \\
\hline ELECTRICITY & Rk & RII & Rk & RII & Rk & RII & Rk & RII & Rk & RII & Rk & RII & Rk & RII & Rk & RII \\
\hline Prepaid & 1 & .64 & 1 & .86 & 1 & .81 & 1 & .81 & 1 & .59 & 1 & .59 & 1 & .65 & 1 & .70 \\
\hline Meter reading & 2 & .36 & 2 & .14 & 2 & .19 & 2 & .19 & 2 & 41 & 2 & .41 & 2 & .35 & 2 & .30 \\
\hline ROAD & ALI & OSHO & $\overline{A P A}$ & & ETI- & $\mathrm{OSA}$ & IKE & & $\mathrm{KE}^{r}$ & & SHC & MOLU & MUS & HIN & SUR & LERE \\
\hline & Rk & RII & Rk & RII & Rk & RII & $\begin{array}{l}\text { Rk } \\
\text { RII }\end{array}$ & & $\begin{array}{l}\text { Rk } \\
\text { RII }\end{array}$ & & Rk & RII & $\begin{array}{l}\text { Rk } \\
\text { RII }\end{array}$ & & Rk & RII \\
\hline $\begin{array}{l}\text { Road with side } \\
\text { walk }\end{array}$ & 1 & .92 & 2 & .67 & 4 & .22 & 1 & 99 & 1 & 85 & 1 & .85 & 3 & .31 & 3 & .35 \\
\hline $\begin{array}{l}\text { Road with cyclist } \\
\text { path }\end{array}$ & 5 & .11 & 4 & .33 & 5 & .00 & 5 & 02 & 5 & 07 & 5 & .07 & 4 & .16 & 5 & .12 \\
\hline Road with drainage & 2 & .67 & 1 & .67 & 3 & .30 & 3 & 34 & 3 & 33 & 3 & .33 & 2 & .59 & 2 & .37 \\
\hline $\begin{array}{l}\text { Road with street } \\
\text { light }\end{array}$ & 3 & .17 & 5 & .00 & 1 & .99 & 2 & 39 & 2 & 56 & 2 & .56 & 1 & .80 & 1 & .99 \\
\hline $\begin{array}{l}\text { Just memorable } \\
\text { road }\end{array}$ & 4 & .13 & 3 & .33 & 2 & .37 & 4 & .25 & 4 & .19 & 4 & .19 & 5 & .14 & 4 & .14 \\
\hline
\end{tabular}

On the kind of road respondents prefer in all eight local government area surveyed: Roads with sidewalks were ranked first in Alimosho, Ikeja, Ketu, and Shomolu. Road with traffic light ranked first in Eti-Osa, Mushin, and Surulere while roads with drainage were ranked first in Apapa. Road with cyclist path was rank second in Ikeja, Kosofe and Mainland. Road with drainage was ranked second in Alimosho, Mushin and Surulere while just motorable road was ranked second in Eti-Osa. Road with cyclist path was ranked low by all respondents from Alimosho, Apapa, Eti-Osa, Ikeja, Ketu, Shomolu, Mushin and Surulere Local Government Area in this study. The peculiar circumstances of each area will likely determine their service option for infrastructure. Demand orientation means that all process in service provision respond to the consumer. A demand based approach therefore implies that the beneficiaries choose services from a menu of alternatives having price tags associated with them. The findings therefore align with the views expressed in (Kessides 1997, 2004, World Bank 2006). Adhering to this will also enhance WTP, cost recovery service/neighborhood sustainability. According to Fox (1995),Cotton and Franeys (1993) and World Bank 2006, Kessides 1995 and 2004 Mabogunje (1993) Choynoski (2002) and Otegbulu (2011), users are the major clients for infrastructure service and must be part of project design. 
Table 3: Mean WTP and Expenditure

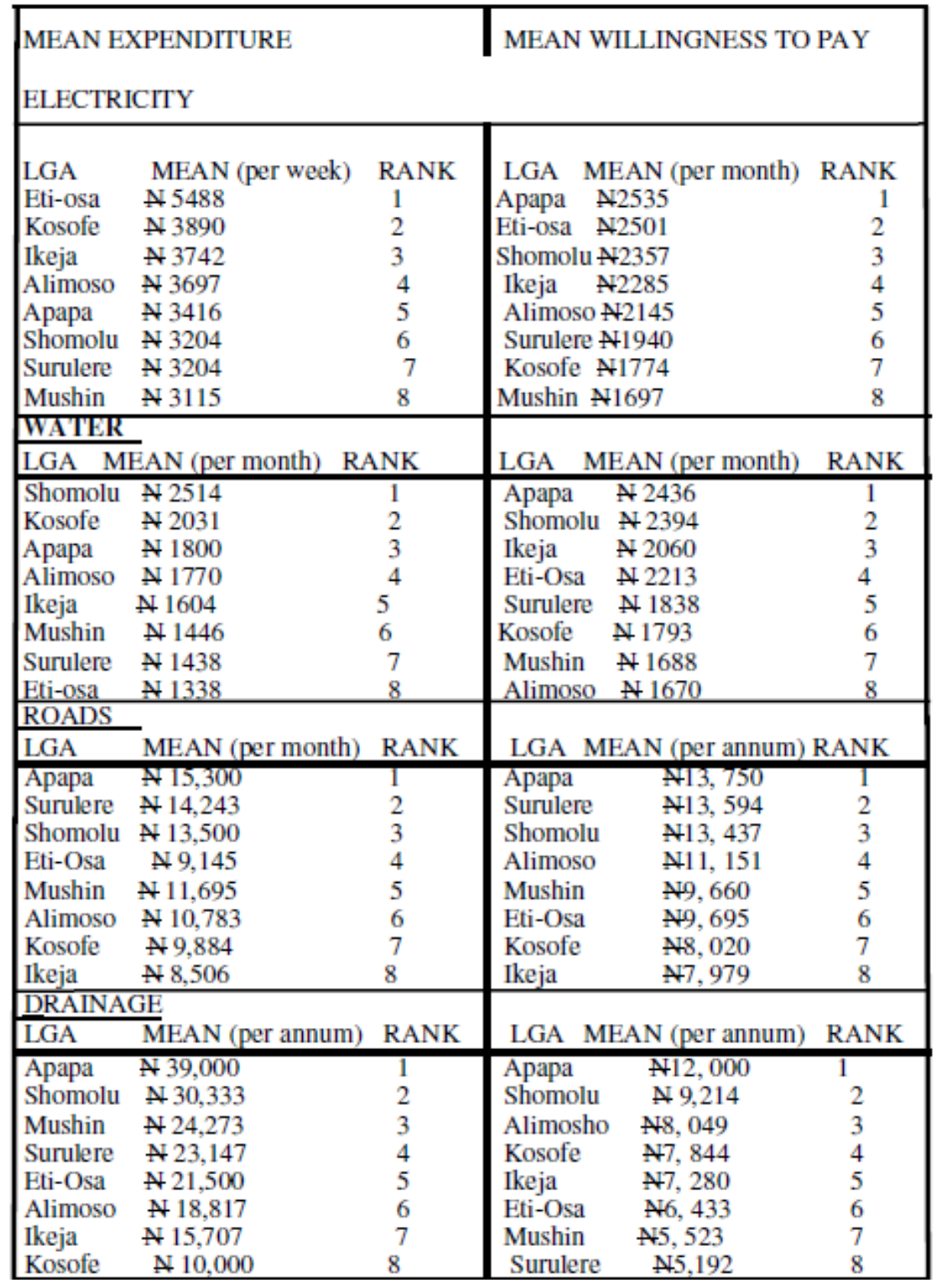

Results from this strengthens the need to consider service or technical option in infrastructure provision as the manner each area wants infrastructure to be provided depends on their peculiar circumstances; affordability and past experience. Households resort to alternative sources of power in the absence of public electricity. The mean cost of running generators by households in the various local government areas as shown in table 9 is between $\$ 3000$ and $\$ 5000$ per week. This is an average of $\$ 500$ - $\$ 800$ per day. The implication of this is that if electricity becomes regular, households would be willing to pay any amount less than their averting expenditure they spend. The expenditure pattern and WTP can be used in tariff setting for electricity. This is in line with the views expressed in literature by Gunatilake (2006) and Otegbulu (2011).

High cost of running generators also affects household spendable income as it constitutes a constraint on their budget. When pipe borne water service is non-functional or epileptic, households resort to informal sources. The table above shows the amount spent by households on alternative water supply on monthly basis. The highest expenditure is in Shomolu local government area with a mean expenditure of 2,514.30 while Eti-Osa has the least mean expenditure of $\$ 1,338.80$. This could also form a basis for setting water tariff in the study area when combined with WTP.

Table 3 also shows cost incurred by car owning households due to damages arising 
from plying bad roads. Residents of Apapa local government incur the highest cost of $\$ 15,300.00$ per month while Ikeja local government area has the least mean cost of $\$ 8,506.00$. The residents are also desirous of improved roads and are willing to pay for it.

Further to the above, poor drainage condition leads to flooding which causes damage to life and property. Table 9 below shows that Apapa local government area incurs the highest loss due to flooding as the value of property lost is $39,000.00$ while the least cost of $\$ 10,000.00$ is incurred by Kosofe local government area. The table above also shows the evidence of willingness to pay (WTP) for improvement of the various infrastructure. For electricity Apapa has the highest WTP of 2,535 per month while Mushin has the least WTP of $1,697.00$. For water Apapa has the highest WTP of $\$ 2,436$ while Alimosho has the least WTP of 1,670.00. The highest WTP for road which is in sum of $13,750.00$ is from Apapa local government area while the least WTP is from Ikeja local government area in the sum of $\$ 7,977.00$. The highest WTP for drainage of 12,000.00 is from Apapa local government while the least WTP is $\$ 5,192.00$ is from Surulere local government.

Households are willing to pay to avoid mitigation expenditure arising from poor condition of infrastructure in the study area. There is no doubt that if infrastructure is provided in line with user demand preferences, WTP will be high with obvious implication to economic sustainability of the services provided

\section{Conclusion}

The study indicates that urban households spend much money on provision of infrastructures from informal sources. Service capacity can be greatly increased by making existing investment to be more productive. Whenever there is need to embark on new investments, the technology must be appropriately selected to meet households' preferences and their ability to provide required maintenance. Planning has to be designed through a system that must be able to identify and meet demand of all users across different income strata in urban areas. Good planning must be responsive to the consumer. This will necessitate movement to a demand orientation which represents a shift from the traditional focus on expanding capacity through command approach. There is an urgent need to address the deteriorating infrastructure condition in the study area in line with user demand preferences as this will enhance willingness to pay, cost recovery and sustainability. Poor infrastructure condition constraints neighbourhood sustainability, but residents incur a lot of averting expenditure which is a good indication that they are willing to pay for improved and sustainable infrastructure provision in line with their demand.

\section{References}

Abdu, M.S. (1997). Urban Municipalities in Nigeria: The missing link in Local Governance and Development. Nigerian Urban Forum, 1(3): 7 - 10

Amis, P. and Kumar, S. (2000). Urban Economics Growth Infrastructure and Poverty in India: Lessons from visaulapatnam. Environment and Urbanization, 12(1): 185-196.

Andres, L.A., Guasch, J.L., Haven, T. and Foster, V. (2008). The Impact Of Private Sector Participation In Infrastructure; Lights, Shadows And The Road Ahead Access, Affordability And Alternatives. World Bank Washington D.C.

Arrosi, S. (1996). Health in metropolitan Buenos Aires. Environment and Urbanization 8(2): $43-70$

Bagi, F.S. (2002). Economic Impact of Water sewer Facilities on Rural and Urban Communities. Rural America, Volume 17(4): 44-49

Barnejee, S.G., Morella. E. (2011). Africa's Water and Sanitation Infrastructure: Access Affordable and Alternatives. World Bank Washington D.C.

Brook, P. J. and Irvin, T.C (2003). Infrastructure for Poor People: Public Policy for Private Provision. World Bank Washington D.C.

Calderon, C. and Server, L. (2008). Infrastructure and Economic Development in Sub-saharan Africa. World Bank, Washington D.C.

Choynowski, P. (2002). Measuring Willingness to Pay for Electricity.ERD. Technical Notes Series No. 3. Asian Development Bank Manila.

Cotton, A. and Franceys, R. (1993). Infrastructure for the Urban Poor in Developing Countries. Paper 10307 Journal of Urban Infrastructure in Developing countries Sept 1993, pages $129-138$. 
Ebernard, A., Rosnes, O., Shkaratan. M. and Vennemon, H. (2011). Africa's Infrastructure, Investment, Integration, Efficiency. World Bank, Washington D.C.

Foster, V. and Tre, J. (2003). Measuring the Impact of Energy Investments on the Poor in Brook P.J.And Irvin. T. C. Infrastructure for the Poor, Public Policy For Private Provision. World Bank, Washington D.C. 1-20.

Fox, W.F. (1995). Strategic Options for Urban Infrastructure Management.World Bank, Washington D.C.

Goodman, A.S. and Hastak, M. (2006). Infrastructure Planning Handbook ASCE Publishers U.S.A.

Guntatilake, H., Yang, J., PaHanayak, S. and Berg, C. (2006).Willingness to Pay and Design for Water Supply and Sanitation Projects: A case Study. E.R.D Technical Note No. 19, Asian Development Bank Hanson R. (ed) (1984). The state of Art. Perspective on Urban Infrastructure National Academy, Press, Washington D.C: $67-109$

Hensher, D., Shore, N. and Train, K. (2005). Households Willingness to Pay for Water. Journal of Environmental and Resource Economics, 32: 509-531

Kaufman, S. and Snappe, K. (1997). Public attitudes towards urban infrastructure. The North east Ohio experience. Journal of Public Works Management Policy. 1(3): 224- 244.

Kessides, C. (1995). The contribution of Infrastructure to EconomicDevelopment. A review of Experience and Policy Implication. World Bank, Washington D.C.

Kessides, C (1999). How to Relate User Demand and Services. The World Bank, Washington D.C. Kessides, C. (1993). The Contributions of Infrastructure to Economic Development: A Review of Experience and Policy Implications. World Bank Discussion Papers No. 213.

Kessides, C. (2001). A Framework of Economic Policies for Urban Upgrading.World Bank, Washington D.C.

Littlefair, K. (1998). Willingness to pay for water at the Household level: Individual financial responsibility for water consumption. MEWREW occasional Paper No 26. Water Issues Study Group
School of Oriental and African Studies (SOAS) University of London.

Montes de Oca, G.S., Bateman, I.J., Tinch, B. and Moffat, P.G. (2004). Assessing the willingness to pay for maintained improved water supplies in Mexico City (SERGE working paper ECM 03 -11).

Montes De Oca, G.S., Bateman. I. (2006). Scope Sensitivity In Households Willingness To Pay For Maintained And Improved Water Supplies In Mexico City: Investigating The Influence Of Baseline Supply Quality And Income Distribution Upon Stated Preferences .

Discussion Paper No 115. Center for Sound and Economic Research in the Global Environment, University of East Anglia, Norwhich U.K.

Montes De Oca, G.S., Bateman, I. J. Tinch, R. and Moffat, P.G. (2006). Assessing the Willingness to Pay for Maintained and Improved Water Supply in Mexico. Working Paper ECM 03-11. Center for Social and Economic Research in the Global Environment.

Morrison, M. and Nalder, G. (2009). Willingness to Pay for Improved Quality of Electricity Supply across Business Type and Location. The Energy Journal 30(2): 117-133.

Mycoo, M. (2005). Utility Performance and Consumer Willingness to Pay for Water in the early 1990's: Case study of Trinidad. West Indian Journal of Engineering, 27(2): $1-2$.

Ogu, V.I (2000). Stakeholders partnership in Infrastructure Provision and Management in Developing World City. Lesson from sustainable Ibadan project Habitat for Humanity International.

Organization for Economic Co-Operation and Development (OECD) (2008). Infrastructure to 2030, Policy Brief.

Otegbulu, A.C. (2010). Assessment of User Demand Preferences of Urban Infrastructure in Lagos Metropolis Using Contingent valuation model. $\mathrm{PhD}$ Thesis submitted to the School of Postgraduate Studies Enugu State University of Science and Technology, Nigeria

Otegbulu, A.C. (2001). Contingent Valuation Model for Assessing Electricity Demand. Journal of Financial Management of Property and Construction. Emerald Publishers U.K: Pf; 126-146. 
Oum, T.H. (1990). Survey of Recent Estimates of Price Elasticities of demand for Transport planning and Policy Research Working Papers, No 359, World Bank, Infrastructure and Development, Washington D.C

Perman, R., Ma, Y., Mcgilrray, J. and Gemmen, M. (2003).Natural Resources and Environmental Economics. Person U.K.

Rizzi, L. I. and Ortuzar, J. (2006). Estimating the willingness to pay for Road Safety Transport Review, 26: 471 - 485.

United States Agency for International Development (USAID) (1996). Environmental Health Project Coping with Intermittent Water Supply: Problems and Prospects, (Dehna Dun UltarPradesh, India. Activity Report), Washington D.C. USA.

Virgee, K. (2005). The Willingness to Pay for Changes in Water, Waste Water and Electricity Services in Trinidad and Tobago, Department of Civil Engineering, McGill University.
Whittington, D. (2003). Ethical issues with contingent valuation surveys in developing countries: A note on informed consent and other concerns. Environmental \& Resource Economics, 28, 507-515.

Whittington, D., Okorafor, A., Akore, A., and Miphail, A. (1989). Cost Recovery Strategy for Rural Water Delivery in Nigeria. Infrastructure and Urban Development, World Bank, Washington D.C.

World Bank (1995). Restoring Urban Nigeria: A Strategy for restoring urban infrastructure and services in Nigeria. The World Bank, Washington D.C.

World Bank (2006). Infrastructure at Crossroads. World Bank Washington D.C.

World Bank (2008). Strategic Communication for Privatization, Public Private Partnership and Private Participation in Infrastructure Projects. World Bank Washington D.C. 